\title{
Identification of Sexes in Poultry Using DNA Based Methods
}

\author{
${ }^{1}$ Manoj Kumar Singh, ${ }^{2}$ Jinu Manoj" \\ ${ }^{1}$ Department of Livestock Production Management \\ 2Department of Veterinary Public Health and Epidemiology \\ College of Veterinary and Animal Sciences \\ Sardar Vallabhbhai Patel University of Agriculture and Technology, Meerut, India.
}

\begin{abstract}
Genetic sex of most of avian species cannot be identified by the external appearance especially for young birds. Identification of sex in avians can be performed by many techniques, but DNA based methods are more reliable and are most convenient method of sex differentiation in commercially valuable birds or endangered birds. The constitution of sex chromosomes of female birds is ZW and ZZ for males. The DNA sequence that is present only on the $W$ chromosome, which is conserved among species, can be used as a target of PCR-based sex identification. The chromobox-helicase-DNA-binding gene or CHD gene is remarkably conserved in females as $C H D-W$ and has an analogous sequence on $Z$ chromosome (CHD-Z). The specific $P_{2}$ $P_{8}$ primers amplify the homologous parts of CHD-W as well as CHD-Z, could be the best way to identify the sex of many avian species. Other molecular methods like RAPD, RFLP, AFLP, micro and minisatellites are some of the efficient sex differentiation techniques in avians.
\end{abstract}

Keywords: $C H D$ gene, DNA, identification, poultry, sex

\section{INTRODUCTION}

Identification of the sex of birds is important for captive breeding of endangered species and also for basic research such as molecular ecology and developmental biology. Genetic sex of most of avian species cannot be identified by the external appearance especially for young birds [1]. Application of the polymerase chain reaction (PCR) for the identification of genetic sexes of birds is ideal because it requires only a small sample and minimizes trauma to birds. The feathers can be used as source of genomic DNA. DNA extraction from feathers is friendly to birds as it reduces handling stress, blood loss and chance of infection in them [2]. The constitution of sex chromosomes of birds is ZW for females and ZZ for males. Thus any DNA sequence that is present only on the $\mathrm{W}$ chromosome and is widely conserved among species would be a target of PCR-based sex identification [3]. Sex determination of various birds was reported by using molecular methods $[4,5,6,7,8]$.

DNA typing in avian species is first reported [9] based on repetitive sequences, of EcoRI family, which was found in the DNA of the chicken W chromosome using XhoI family probe. The XhoI and EcoRI family repetitive sequences were highly specific to the $\mathrm{W}$ chromosome $[9,10]$ and are clearly identifiable after a relatively small number of reaction cycles in PCR [11]. The chicken W chromosome-specific XhoI repetitive unit can be used as a probe for identifying the sex of early embryos [12, 13, 14]. A novel model for the development and use of a one-step, SYBR green-based real-time PCR and melting curve analysis for the rapid and specific detection and verification of the gender of birds using sex-specific or $\mathrm{P}_{2} / \mathrm{P}_{8}$ primer sets was reported [15]. This allowed molecular sexing of birds in a gel-free, quick, and inexpensive as well as high-throughput manner.

\section{RFLP}

Sex identification of avian embryos at early stages of development can be achieved by restriction fragment length polymorphism technique [16]. This method is recommended as a management tool for endangered species conservation programs. The RFLP technique has been used as complementrary method in minisatellite [17] and DNA probes like DQSG10, pV47-2, pMg1 for sex identification in geese, brown skua and purple swanphen respectively $[18,19]$. 


\section{RAPD}

Random amplified polymorphic DNA (RAPD) markers could be used in sex identification. If the selected RAPD marker is on the $\mathrm{W}$ chromosome, it would be amplified only in females and provides a female specific marker [20,21, 22]. Since the length of primers determines the length of target size, when its length decreases primers could encounter a great number of target sites and increase the chance of amplifying a sex specific locus and this method is species-specific [21]. A female-specific DNA marker using RAPD fingerprinting was identified for pigeon [23], Columbidae birds [24] and ostrich (Struthio camelus) [25].

\section{AFLP}

Amplified Fragment Length Polymorphism (AFLP) method has been used in ostrich (Struthio camels) and shag (Phalacrocorax aristotelis) to sex identification [26, 27, 28].

\section{Micro and minisatellites}

Use of microsatellite or short tandem repeats (STRs) were reported for sex identification in birds [29, 30, 31]. The use of minisatellites or VNTRs (Variable number of tandem repeats) was also reported for sex differentiation. The human minisatellite probe 33.15 was used for sex identification in South American parrots [17, 32].

\section{CHD genes in avians}

CHD gene composes an improved basis for DNA sexing [1, 33, 34, 35]. CHD-W found on the chicken $\mathrm{W}$ chromosome [1] and a unique sequence EE0.6 (0.6 kb EcoRI fragment) found on the long arm of the chicken $\mathrm{W}$ chromosome [4] have been utilized for the purpose of sex identification. The latter sequence is widely conserved on the $\mathrm{W}$ chromosome, not only in Carinatae species but also in Ratitae species [5]. However, both CHD and EE0.6 sequences have their counterpart sequences on the $\mathrm{Z}$ chromosome, such as CHD-Z and XH0.6RSM in the oriental white stork (Ciconia boyciana), and the similarity of $\mathrm{W}$ - and Z-linked sequences is variable among species, which causes occasional ambiguous results in the sex determination $[1,4]$. The EE0.6 sequence found on the long arm of the chicken W chromosome is conserved in all species of birds both in Carinatae and Ratitae [4,5]. The sex of 36 species belonging to 16 different orders of Carinatae was determined by comparing the Wand Z-linked EE0.6 sequences [3].

Multiple primers have been designed to screen the intron size difference in CHD genes. The most commonly used primer pairs for sex identification in avian species were $\mathrm{P}_{2}-\mathrm{P}_{8}[1]$ and $1237 \mathrm{~L}-$ $1237 \mathrm{H}$ [33]. In most avian species the length of CHD gene is slightly longer in the $\mathrm{W}$ chromosome as compared to the $\mathrm{Z}$ due to the presence of additional DNA bases in intron region. However in some species like pukeko, most owls and hawks intron size of CHDW and CHDZ genes show very similar sizes [1, 33]. In Ratitae, SS and $\mathrm{OSM}_{5}$ primers were used in sex identification of ostrich which belongs to Ratitae family [36, 37]. PCR-based methods to sex-type ostriches were reported [28, 36, 38]. Identification of sex of the endangered old world vultures by PCR based method, facilitated the breeding of these birds in captivity [39].

DNA sexing techniques which target the conserved CHD genes in owls [40] and in pin-tailed Manakin (Ilicura militaris) [41] using the CHD genes were also reported. Sex identification in Blackfaced Spoonbill amplified CHD-W and CHD-Z genes, with products of 658 and 464 base pair respectively [42], while sex determination in Cockatoo (parrot) species (Nymphicus hollandicus) from feather also possible [2].

The highly conserved CHD-W gene can be used as a universal tag for avian sexing based on singlestrand conformation polymorphism (SSCP) protocol [43]. The sex determination with primers USP $_{1}$ and $\mathrm{USP}_{3}$ is applicable for Galliformes and some Falconiformes and the primers $\mathrm{P}_{2}$ and $\mathrm{P}_{3}$ for Galliformes. The molecular evolution of the coding sequence of the CHD1Z and CHD1W genes revealed that these two genes evolve independently but are highly conserved at nucleotide as well as amino acid levels [34].

Similar reports were also found in neognath and paleognath bird CHD sequences [44]. Palaeognathous birds have been morphologically conserved karyotypes and less differentiated ZW sex chromosomes. The molecular basis of chromosome orthologies and sex chromosomal differentiation by comparative chromosome painting, revealed that the karyotypes and sex 
chromosomes of palaeognathous birds are highly conserved not only morphologically, but also at the molecular level [7]. The comparative cytogenetic maps of the $\mathrm{Z}$ and $\mathrm{W}$ chromosomes of palaeognathous birds, Eudromia elegans and Struthio camelus revealed that there are partial deletions in the proximal regions of the $\mathrm{W}$ chromosomes in the two species and the $\mathrm{W}$ chromosome is more differentiated in E. elegans than in S. camelus [8].

Gender identification in Zebra Finches (Taeniopygia guttata) by a W-chromosome linked marker is reported [45]. The structure and brain expression of the sex chromosome genes CHD1Z and CHD1W in Zebra Finches revealed that the two genes maintained a high degree of similarity especially within the $\mathrm{C}, \mathrm{H}$ and $\mathrm{D}$ domains, but outside of these regions larger differences were observed [6]. CHDIZ mRNA was expressed at a higher level in the male brain than in the female at various post-hatch ages and the proteins have been also diverged in their function. Two genes, ATP5A1 and CHD1, which was assigned to the female-specific $\mathrm{W}$ chromosome of birds, were present on the $\mathrm{Z}$ chromosome also [46]. This indicated a common ancestry of the two sex chromosomes, with the evolution from a pair of autosomes.

\section{Other genes}

The DMRT1 gene which is $\mathrm{Z}$ linked is expressed early in male development [47] and the PKCIW gene which is W linked which appear early in female gonads [48]. The Z-linked gene, DMRT1, supports the Z-dosage model of avian sex determination and two W-linked genes, ASW and FET1, represent candidate female determinants $[49,50]$.

The W-linked gene, HINTW, is expressed in the gonads of female birds just before sexual differentiation and is distinctly different from its homolog on the $\mathrm{Z}$ chromosome (HINTZ), thus ,makes a candidate gene in avian sex determination [48]. HINTW showed evidence of adaptive molecular evolution related to female development [51]. The phylogenetic analysis within galliform birds (chicken, turkey, quail, and pheasant) showed that individual HINTW copies within each species are more similar to each other than to gene copies of related species [52].

The presence of WPKCI gene on the W chromosome with its locus in the nonheterochromatic end region was found to be express significantly greater during the early stages of development of female embryos [48]. WPKCI gene is involved in triggering the differentiation of ovary by interfering with the function of protein, PKCI and it is expressed in early female embryos, which can be used for determination of sex in avians. The female specific WPKCI gene was conserved among all the Carinatae species of birds examined by them.

The sex of quail and duck embryos can be identified based on Sox9 gene expression [53]. Sox9 is a member of the Sry-type HMG-box (Sox) gene family. It encodes a transcription factor and is important for sexual differentiation in chicken.

\section{Conclusion}

Identification of sex in avians can be performed by many techniques, but DNA based methods are more reliable. It is most convenient method of sex differentiation in commercially valuable birds or endangered birds. The feathers can be used as source of genomic DNA. DNA extraction from feathers is friendly to birds as it reduces handling stress, blood loss and chance of infection in them. Molecular methods including RAPD, AFLP, RFLP, micro and minisatellites, amplification of CHD genes are some of the efficient sex differentiation techniques in avians. The $\mathrm{P}_{2}-\mathrm{P}_{8}$ primer pairs for the conserved dimorphic genes of CHD sequence could be the best way to identify the sex of many avian species.

\section{REFERENCES}

[1] Griffiths, R., Double, M.C., Orr, K. and Dawson, R.J.G. 1998. A DNA test to sex most birds. Molecular Ecology. 7:1071-1075.

[2] Cerit, H. and Avanus, K. 2007. Sex identification in avian species using DNA typing methods. World's Poultry Science Journal. 63: 91-99.

[3] Itoh, Y., Suzuki, M., Ogawa, A., Munechika, I., Murata, K. and Mizuno, S. 2001. Identification of the sex of a wide range of Carinatae birds by PCR using primer sets selected from chicken EE0.6 and its related sequences. The Journal of Heredity. 92: 315-321. 
[4] Ogawa, A., Solovei, I., and Hutchison, N. 1997, Molecular characterization and cytological mapping of a non-repetitive DNA sequence region from the $\mathrm{W}$ chromosome of chicken and its use as a universal probe for sexing Carinatae birds. Chromosome Res. 5: 93-101.

[5] Ogawa, A., Murata, K. and Mizuno, S. 1998. The location of Z- and W-linked marker genes and sequence on the homomorphic sex chromosomes of the ostrich and the emu. Proceedings of the Natural Academic Sciences. USA. 95: 4415-4418.

[6] Agate, R.J., Choe, M. and Arnold, A.P. 2004. Sex Differences in Structure and Expression of the Sex Chromosome Genes CHDIZ and CHDIW in Zebra Finches. Mol. Biol. Evol. 21: 384396.

[7] Nishida-Umehara, C., Tsuda, Y., Ishijima, J., Ando, J., Fujiwara, A., Matsuda, Y. and Griffin, D.K. 2007. The molecular basis of chromosome orthologies and sex chromosomal differentiation in palaeognathous birds. Chromosome Research. 15: 721-734.

[8] Yayoi, T., Chizuko, N., Junko, I., Kazuhiko, Y. and Yoichi, M. 2007. Comparison of the Z and $\mathrm{W}$ sex chromosomal architectures in elegant crested tinamou (Eudromia elegans) and ostrich (Struthio camelus) and the process of sex chromosome differentiation in palaeognathous birds. Chromosoma.116: 159-173.

[9] Saitoh, Y., Saitoh, H., Ohtomo, K. and Mizuno, S. 1991. Occupancy of the majority of DNA in the chicken W chromosome by bent-repetitive sequences. Chromosoma 101: 32-40.

[10] Kodama, H., Saitoh, H., Tone, M., Kuhara, S., Sakaki, Y. and Mizuno, S. 1987. Nucleotide sequences and unusual electrophoretic behavior of the W chromosome-specific repeating DNA units of the domestic fowl, Gallus gallus domesticus. Chromosoma. 96: 18-25.

[11] Clinton, M., Haines, L., Belloir, B. and McBride, D. 2001. Sexing chick embryos: a rapid and simple protocol. British Poultry Science. 42: 134-138.

[12] Saitoh, H., Harata, M. and Mizuno, S. 1989. presence of female specific bent-repetitive DNA sequences in the genomes of turkey and pheasant and their interactions with W-protein of chicken. Chromosoma 98: 250-258.

[13] Petite, J.N. and Kegelmeyer, A.E. 1992. Sex determination of chick embryos using a W chromosome-specific oligonucleotide probe and PCR. Proceedings of the XIX World's Poultry Congress. Amsterdam. p: 531.

[14] Nakabayashi, O., Kikuchi, H., Kikuchi, T. and Mizuno, S. 1998. Differential expression of genes for aromatase and estrogen receptor during the gonadal development in chicken embryos. J. Mol. Endocrinol. 20: 193-202.

[15] Chang, H., Cheng, C., Gu, D., Chang, D., Su, S., Wen, C., Chou, Y., Chou, T., Yao, C., Tsai, C. and Cheng, C. 2008. High-throughput avian molecular sexing by SYBR green-based real-time PCR combined with melting curve analysis. BMC Biotechnology. 8: 12- 20.

[16] Dutton, C.J. and Tieber, A. 2001. A modified protocol for sex identification of in ovo avian embryos and its application as a management tool for endangered species conservation programs. J. Zoo. Wildl. Med. 32: 176-180.

[17] Miyaki, C.Y., Duarte, M.B., Caparroz, R., Nunes, A.V. and Wajntal, A. 1997. Sex identification of South American Parrots using the human minisatellite probe 33.15. The Auk. 114: 516-520.

[18] Quinn, T.W., Cooke, F. and Bradley, N.W. 1990. Molecular sexing of geese using a cloned Z chromosomal sequence with homology to the W chromosome. The Auk. 107: 199-202.

[19] Millar, C.D., Lambert, D.M., Anderson, S. and Halverson, J.L. 1996. Molecular sexing of communally breeding pukeko: An important ecological tool. Molecular Ecology. 5: 289.

[20] Williams, J.G.K., Rubelik, A.R., Livak, K.J., Rafalski, J.A. and Tingey, S.V. 1990. DNA polymorphisms amplified by arbitary primers are useful as genetic markers. Nucleic Acids Res. 18: 6531-6535.

[21] Griffiths, R. and Tiwari, B. 1993. The isolation of molecular genetic markers for the identification of sex. Proc. Natl. Acad. Sci. USA. 90: 8324-8326.

[22] Huang, M.C., Lin, W.C., Horng, Y.M., Rouvier, R. and Huang, C.W. 2003. Female-specific DNA sequences in geese. Br. Poult. Sci. 44: 359-364.

[23] Horng, Y.M., Wu, C.P., Wang, Y.C., Huang, M.C. 2006. A novel molecular genetic marker for gender determination of pigeons. Theriogenology. 65:1759-1768. 
[24] Wu, C.P., Horng, Y.M., Wang, R.T., Yang, K.T. and Huang, M.C. 2007. A novel sex-specific DNA marker in Columbidae birds. Theriogenology. 67: 328-333.

[25] Bello, N. and Sanchez, A. 1999. The identification of a Sex-specific DNA marker in the ostrich using a random amplified polymorphic DNA (RAPD) assay. Molecular Ecology. 8: 667-669.

[26] Vos, P., Hogers, R., Bleaker, M., Reijans, M., Van de Lee, T., Hornes, M., Fritjers, A., Pot, J., Peleman, J., Kuiper, M. and Zabeau, M. 1995. AFLP: a new technique for DNA fingerprinting. Nucleic Acids Res. 23: 4407- 4414.

[27] Griffiths, R. 2000. Sex identification using DNA markers. In: Molecular methods in ecology (Backer, A.J. ed.), pp: 295-321. Blackwell Science, London.

[28] Griffiths, R. and Orr, K. 1999. The use of amplified fragment length polymorphism (AFLP) in the isolation of sex-specific markers. Molecular Ecology. 8: 671-674.

[29] Longmire, J.L., Maltbie, M., Pavelka, R.W., Smith, L.M., Witte, S.M., Ryder, O.A., Ellsworth, D.L. and Baker, R.J. 1993. Gender identification in birds using micro satellite DNA fingerprint analysis. The Auk. 110: 378-381.

[30] Nesje, M. and Roed, K.H. 2000. Sex identification in falcons using microsatellite DNA markers. Hereditas. 132: 261-263.

[31] Nesje, M., Roed, K.H., Lifield, J.T., Lindberg, P. and Steen, O.F., 2000. Genetic relationships in the peregrine falcon (Falco peregrinus) analysed by microsatellite DNA markers. Mol. Ecol. 9: 53-60.

[32] Graves, J., Ortega-Ruano, J. Ad Slater, P.J.B. 1993. Sex ratio of chicks in the Shag (Phalacrocorax aristotelis) determined by a female-specific band in DNA finger printing. Ibis. 135: 470-472.

[33] Kahn, N.W., John, J. and Quinn, T. 1998. Chromosome-specific intron size differences in the avian CHD gene provide an efficient method for sex identification in birds. The Auk. 115: 10741078.

[34] Fridolfsson, A.K. and Ellegren, H. 1999. Molecular evolution of the avian CHD1 genes on the Z and W sex chromosomes. Genetics. 155: 1903-1912.

[35] Singh, M.K., Singh, H.N., Gupta, A., Shukla, P.K. and Sharma, D. 2010. Size variation in the intronic region of CHD-W and CHD-Z genes among domestic galliformes species. Indian Journal of Poultry Science, 45(1): 66-67.

[36] Malago, Jr. W., Franco, H.M., Matheucci, Jr.E., Medaglia, A. and Henrique-Silva, F. 2002. Large scale sex typing of ostriches using DNA extracted from feathers. BMC Biotechnology. 2:19-22.

[37] Jensen, T., Pernasetti, F.M. and Durrant, B. 2003. Conditions for repid sex determination in 47 avian species by PCR of genomic DNA from blood, shell-membrane blood vessels and feathers. Zoo Biology. 22: 561-567.

[38] Malago. Jr., W., Medaglia, A., Matheucci, Jr., E. and Henrique-Silva, F. 2005. New PCR multiplexes for sex typing of ostriches. Braz. J. Biol. 65: 743-745.

[39] Reddy, A., Prakash, V. and Shivaji, S. 2007. A rapid non-invasive PCR based method for identification of sex of the endangered old world vultures (white-backed and long-billed vultures) Implications for captive breeding programmes. Current Science. 92: 659-662.

[40] Leppert, L., Zadorozhny, T.V., Belthoff, J.R., Dufty, Jr.A.M., Stock, S.L., Kaltenecker, G. and Smith, J.F. 2006. Sex identification in four owl species from Idaho: DNA and morphometrics. $J$. Raptor Res. 40: 43-46.

[41] Anciaes, M. and Lama, S.N.D. 2002. Sex identification of pin-tailed manakins (Ilicura militaris: Pipridae) using the polymerase chain reaction and its application to behavioral studies. Ornitologia Neotropical. 13: 159-165.

[42] Cheng, Y., Kuo, T., Lee, D. and Weng, C. 2006. Sex identification of the Black-faced Spoonbill (Platalea minor). Zoological Studies. 45: 104-113.

[43] Cortes, O., Barroso, A. and Dunner, S. 1999. Avian sexing: an optimized protocol using polymerase chain reaction-single-strand conformation polymorphism. J. Vet. Diagn. Invest. 11: 297-299. 
[44] Garcia-Moreno, J. and Mindell, D.P. 2000. Rooting a Phylogeny with Homologous Genes on Opposite Sex Chromosomes (Gametologs): A Case Study Using Avian CHD. Mol. Biol. Evol. 17: $1826-1832$.

[45] Runciman, D., Zann, R.A. and Murray, N.D.1999. A W-chromosome linked marker for gender identification in the Zebra finch. Anim. Genet. 30: 66-67.

[46] Fridolfsson, A.K., Cheng, H., Copeland, N.G., Jenkins, N.A. and Liu, H. 1998. Evolution of the avian chromosomes from an ancestral pair of autosomes. Proceedings of the National Academy of Sciences. 95: 8147-8152.

[47] Marchant, O., Govoroun, M., D’Cotta, H., McMeel, O., Lareyre, J.-J., Bemot, A., Laudet, V. and Guiguen, Y. 2000. DMRT1 expression during gonadal differentiaion and spermatogenesis in the rainbow trout, Oncorynchus mykiss. Biochim. Biophys. Acta. 1493: 180-187.

[48] Hori, T., S. Asakawa, Y. Itho, N. Shimizu, and S. Mizuno. 2000. Wpkci, encoding an altered form of PKCI, is conserved widely on the avian W chromosome and expressed in early female embryos: implication of its role in female sex determination. Mol. Biol. Cell. 11:3654-3660.

[49] Smith, C.A. and Sinclair, A.H. 2004. Sex determination: insights from the chicken.

[50] Smith, C.A., Roeszler, K.N., Hudson, Q.J. and Sinclair, A.H. 2007. Avian sex determination: what, when and where? Cytogenet. Genome Res. 117: 165-173.

[51] Ceplitis, H. and Ellegren, H. 2004. Adaptive molecular evolution of HINTW, a female-specific gene in birds. Mol. Biol. Evol. 21: 249-254.

[52] Backstrom, N,, Ceplitis, H., Berlin, S. and Ellegre, H. 2005. Gene conversion drives the evolution of HINTW, an ampliconic gene on the female-specific avian $\mathrm{W}$ chromosome. Mol. Biol. Evol. 22: 1992-1999.

[53] Takada, S., Ota, J., Kansaku, N., Yamashita, H., Izumi, T., Ishikawa, M., Wada, T., Kaneda, R., Choi, Y.L., Koinuma, K., Fujiwara, S., Aoki, H., Kisanuki, H., Yamashita, Y., Mano, H. 2006. Nucleotide sequence and embryonic expression of quail and duck Sox9 genes. Gen. Comp. Endocrinol. 145: 208-213. 